\title{
KEJADIAN DIARE PADA SISWA KELAS III, IV, DAN V DI SDN CIPUTAT 02 KOTA TANGERANG SELATAN TAHUN 2018
}

\author{
Tri Okta Ratnaningtyas, Nurwulan Adi Ismaya, Nurhafeni \\ Sekolah Tinggi Ilmu Kesehatan Kharisma Persada \\ Tangerang Selatan, 15417 \\ E-mail:triokta@masda.ac.id
}

\begin{abstract}
ABSTRAK
Diare merupakan penyakit endemis di Indonesia dan juga merupakan penyakit potensial kejadian luar biasa yang sering disertai dengan kematian. Jumlah kasus diare di wilayah kerja Puskesmas Ciputat untuk semua umur ditemukan dan ditangani sebanyak 2.020 kasus. Penelitian ini dilakukan untuk mengetahui faktor-faktor yang berhubungan dengan kejadian diare pada siswa kelas III, IV, dan V di SDN Ciputat 02 Kota Tangerang Selatan tahun 2018. Penelitian ini menggunakan pendekatan kuantitatif dengan desain cross sectional. Populasi dalam penelitian ini adalah semua siswa kelas III, IV, dan V di SDN Ciputat 02 Kota Tangerang Selatan. Sampel dalam penelitian ini sebesar 76 responden yang diambil dengan menggunakan teknik pengambilan sampling yaitu rambang proposional. Pengumpulan data menggunakan kuesioner dan analisa data menggunakan uji chi square. Berdasarkan hasil penelitian menunjukkan bahwa responden yang memiliki pengetahuan baik tentang cuci tangan sebesar $69,7 \%$, yang memiliki pengetahuan baik tentang diare sebesar 63,2\%, yang memiliki pengetahuan baik tentang konsumsi makanan jajanan sebesar 63,2\%, yang memiliki sikap cukup baik tentang cuci tangan sebesar 43,4\%, yang memiliki sikap baik tentang diare sebesar $53,9 \%$, yang memiliki sikap kurang baik tentang konsumsi makanan jajanan sebesar 42,1\%, yang memiliki perilaku baik tentang cuci tangan sebesar 57,9\%, dan yang memiliki perilaku cukup baik tentang konsumsi makanan jajanan sebesar 43,4\%. Berdasarkan uji statistik menunjukkan $\mathrm{p}=0,000$ kurang dari $\alpha=0,005$ artinya ada hubungan antara pengetahuan, sikap, dan perilaku dengan kejadian diare pada siswa kelas III, IV, dan V di SDN Ciputat 02 Kota Tangerang Selatan tahun 2018.
\end{abstract}

Kata kunci: Pengetahuan, Sikap, Perilaku, Dan Kejadian Diare

\begin{abstract}
Diarrhea is an endemic disease in Indonesia and it remains a high burden disease which is leading cause of death. There is a 2.020 cases of diarrhea found in the Ciputat Health Center for all ages. The aim of this researched is to determine factors associated with the incidence of diarrhea in class III, IV, and V of students in Ciputat Elementary School 02 South Tangerang City in 2018. This researched used quantitative approached with cross sectional design. Population in this researched are all students in third, fourth, and fifth grade of Ciputat Elementary School 02 South Tangerang City. The sample in this study amounted to 76 respondents who are taken using a sampling technique that is proportional rambang. Data collection is using questionnaires and data analysis using chi square test. Based on the results of the researched showed that respondents who have good knowledge about hand washing by 69,7\%, who have good knowledge about diarrhea by 63,2\%, who have good knowledge about snack food consumption by 63,2\%, who have a fairly good attitude about hand washing by 43,4\%, who have good attitude about diarrhea by 53,9\%, who have poor attitude about snack food consumption by 42,1\%, who have good behavior about hand washing by 57,9\%, and who have good enough behavior about food consumption by 43,4\%. Based on statistical tests showed that $p=$ 0,000 less than $\alpha=0,005$, means that there is a relationship between knowledge, attitude, and behavior with the incidence of diarrhea in class III, IV, and V of students in Ciputat Elementary School 02 South Tangerang City in 2018.
\end{abstract}

Keywords: Knowledge, Attitude, Behavior, And Incident Of Diarrhea 


\section{PENDAHULUAN}

Diare adalah buang air besar dengan konsistensi cair sebanyak 3 kali atau lebih dalam satu hari (24 jam). Penyakit diare merupakan penyebab utama morbiditas dan mortalitas anak di dunia, terdapat 1,7 miliar kasus diare dan sudah membunuh 760.000 anak yang terjadi setiap tahunnya (WHO, 2017). Berdasarkan Profil Kesehatan Indonesia pada tahun 2016 terjadi 3 kali Kejadian Luar Biasa (KLB) diare dengan jumlah diare 198 orang dan kematian enam orang dengan Case Fatality Rate (CFR) 3,04\% (Departemen Kesehatan RI, 2017).

Menurut data Badan Kesehatan Dunia atau World Health Organization (WHO), setiap tahun 100.000 anak Indonesia meninggal akibat diare, sementara data Departemen Kesehatan menunjukkan di antara 1000 penduduk terdapat 300 orang yang terjangkit penyakit diare sepanjang tahun (Departemen Kesehatan RI, 2015). Diare biasanya ditransmisikan oleh kuman dari tangan yang tidak bersih ke makanan. Kebersihan tangan dapat menentukan perkembangan tingkat populasi kuman yang berada di tangan. Kebiasaan

\section{METODE}

\author{
Penelitian ini menggunakan \\ pendekatan kuantitatif dengan desain
}

mencuci tangan harus dibiasakan sejak kecil, anak-anak merupakan agen perubahan untuk memberikan edukasi baik untuk diri sendiri dan lingkungannya sekaligus mengajarkan pola hidup bersih dan sehat (Departemen Kesehatan RI, 2015).

Berdasarkan hasil studi pendahuluan tentang kejadian diare yang telah dilakukan pada tanggal 11 April 2018 terhadap 30 orang siswa yang terdiri dari 10 siswa kelas IV, 10 siswa kelas V, dan 10 siswa kelas VI, diperoleh hasil bahwa dari 10 orang siswa kelas IV yang mengalami diare tiga bulan terakhir sebanyak 6 siswa dan satu bulan terakhir sebanyak 3 siswa. Sedangkan, 10 siswa dari kelas $\mathrm{V}$ yang mengalami diare tiga bulan terakhir sebanyak 6 siswa dan satu bulan terakhir sebanyak 4 siswa, dan pada 10 siswa kelas VI yang mengalami diare tiga bulan terakhir sebanyak 5 siswa dan satu bulan terakhir sebanyak 3 siswa. Maka, dapat disimpulkan identifikasi masalah dalam penelitian ini adalah masih tingginya angka kejadian diare pada usia anak Sekolah Dasar Negeri Ciputat 02 Kota Tangerang Selatan Tahun 2018.

cross sectional. Populasi dalam penelitian ini adalah semua siswa kelas III, IV, dan 
V di SDN Ciputat 02 Kota Tangerang Selatan. Sampel dalam penelitian ini sebesar 76 responden yang diambil dengan menggunakan teknik pengambilan sampling yaitu rambang proposional. Pengumpulan data menggunakan kuesioner dan analisa data menggunakan uji chi square. Penelitian ini berlokasi di Sekolah Dasar Negeri Ciputat 02, Jalan Pemuda No. 07 Kota Tangerang Selatan Provinsi Banten. Penelitian ini dilakukan selama satu bulan yaitu bulan Mei tahun 2018.

\section{HASIL}

\section{Hasil Analisis Univariat}

\section{a. Karakteristik Responden}

Karakteristik responden pada penelitian ini meliputi umur, sebagaimana dijelaskan pada jenis kelamin, dan kelas tabel 1 di bawah ini:

Tabel 1. Distribusi Frekuensi Karakteristik Responden Berdasarkan Umur, Jenis Kelamin, dan Kelas

\begin{tabular}{|c|c|c|c|}
\hline No. & $\begin{array}{c}\text { Karakteristik } \\
\text { Responden }\end{array}$ & Jumlah & Persentase $(\%)$ \\
\hline \multicolumn{4}{|c|}{ 1. Umur } \\
\hline & a. 8 - 9 tahun & 30 & 39,5 \\
\hline & b. $10-11$ tahun & 44 & 57,8 \\
\hline & c. $\geq 12$ tahun & 2 & 2,6 \\
\hline \multicolumn{2}{|r|}{ Total } & 76 & 100,0 \\
\hline \multicolumn{4}{|c|}{ 2. Jenis Kelamin } \\
\hline & a. Laki-Laki & 33 & 43,4 \\
\hline & b. Perempuan & 43 & 56,6 \\
\hline \multicolumn{2}{|r|}{ Total } & 76 & 100,0 \\
\hline \multirow{4}{*}{\multicolumn{2}{|c|}{$\begin{array}{l}\text { Kelas } \\
\text { a. III } \\
\text { b. IV } \\
\text { c. V }\end{array}$}} & & \\
\hline & & 30 & 39,5 \\
\hline & & 23 & 30,3 \\
\hline & & 23 & 30,3 \\
\hline \multicolumn{2}{|r|}{ Total } & 76 & 100,0 \\
\hline \multicolumn{2}{|c|}{ Berdasarkan distribusi } & & responden \\
\hline \multicolumn{2}{|c|}{ frekuensi karakteristik responden } & & perempuan yaitu sebesar 43 \\
\hline \multicolumn{2}{|c|}{ yang telah dijelaskan dalam tabel } & & responden $(56,6 \%)$, dan sebagian \\
\hline \multicolumn{2}{|c|}{1 diketahui bahwa sebagian besar } & & besar responden berada di kelas \\
\hline \multicolumn{2}{|c|}{ responden berumur 10 sampai 11} & & III yaitu sebesar 30 responden \\
\hline tahun & yaitu sebesar 44 responden & & $(39,5 \%)$ \\
\hline
\end{tabular}

$(57,8 \%)$, sebagian besar 


\section{b. Pengetahuan Responden}

Pengetahuan responden dapat

dijelaskan dalam tabel 2 berikut:

Tabel 2. Pengetahuan Responden

\begin{tabular}{|c|c|c|c|}
\hline No. & Pengetahuan Responden & Jumlah & Persentase (\%) \\
\hline \multirow[t]{5}{*}{1.} & Pengetahuan Responden tentang Cuci Tangan & & \\
\hline & Baik & 53 & 69,7 \\
\hline & Cukup & 13 & 17,1 \\
\hline & Kurang & 10 & 13,2 \\
\hline & Total & 76 & 100,0 \\
\hline \multirow[t]{5}{*}{2.} & Pengetahuan Responden tentang Diare & & \\
\hline & Baik & 48 & 63,2 \\
\hline & Cukup & 26 & 34,2 \\
\hline & Kurang & 2 & 2,6 \\
\hline & Total & 76 & $\mathbf{1 0 0 , 0}$ \\
\hline \multirow[t]{5}{*}{3.} & Pengetahuan Responden tentang Konsumsi Ma & kanan Jaja & \\
\hline & Baik & 48 & 63,2 \\
\hline & Cukup & 26 & 34,2 \\
\hline & Kurang & 2 & 2,6 \\
\hline & Total & 76 & 100,0 \\
\hline
\end{tabular}

Berdasarkan tabel 2 diketahui bahwa pada pengetahuan tentang cuci tangan, sebagian besar responden memiliki pengetahuan yang baik tentang cuci tangan yaitu sebesar 53 responden $(69,7 \%)$.

Pada pengetahuan tentang diare diketahui bahwa sebagian besar responden memiliki pengetahuan yang baik tentang diare yaitu sebesar 48 responden $(63,2 \%)$.

Pada pengetahuan tentang Konsumsi Makanan Jajanan diketahui bahwa sebagian besar responden memiliki pengetahuan yang baik tentang konsumsi makanan jajanan yaitu sebesar 48 responden $(63,2 \%)$.

\section{c. Sikap Responden}

Sikap responden tentang dapat dijelaskan dalam tabel 3 berikut:

Tabel 3. Sikap Responden

\begin{tabular}{crcc}
\hline No. & \multicolumn{1}{c}{ Pengetahuan Responden } & Jumlah & Persentase (\%) \\
\hline 1. & Sikap Responden tentang Cuci Tangan & & \\
Baik & 14 & 18,4 \\
Cukup & 33 & 43,4 \\
Kurang & Total & 29 & 38,2 \\
\hline \multicolumn{2}{r}{} & $\mathbf{7 6}$ & $\mathbf{1 0 0 , 0}$ \\
\hline
\end{tabular}




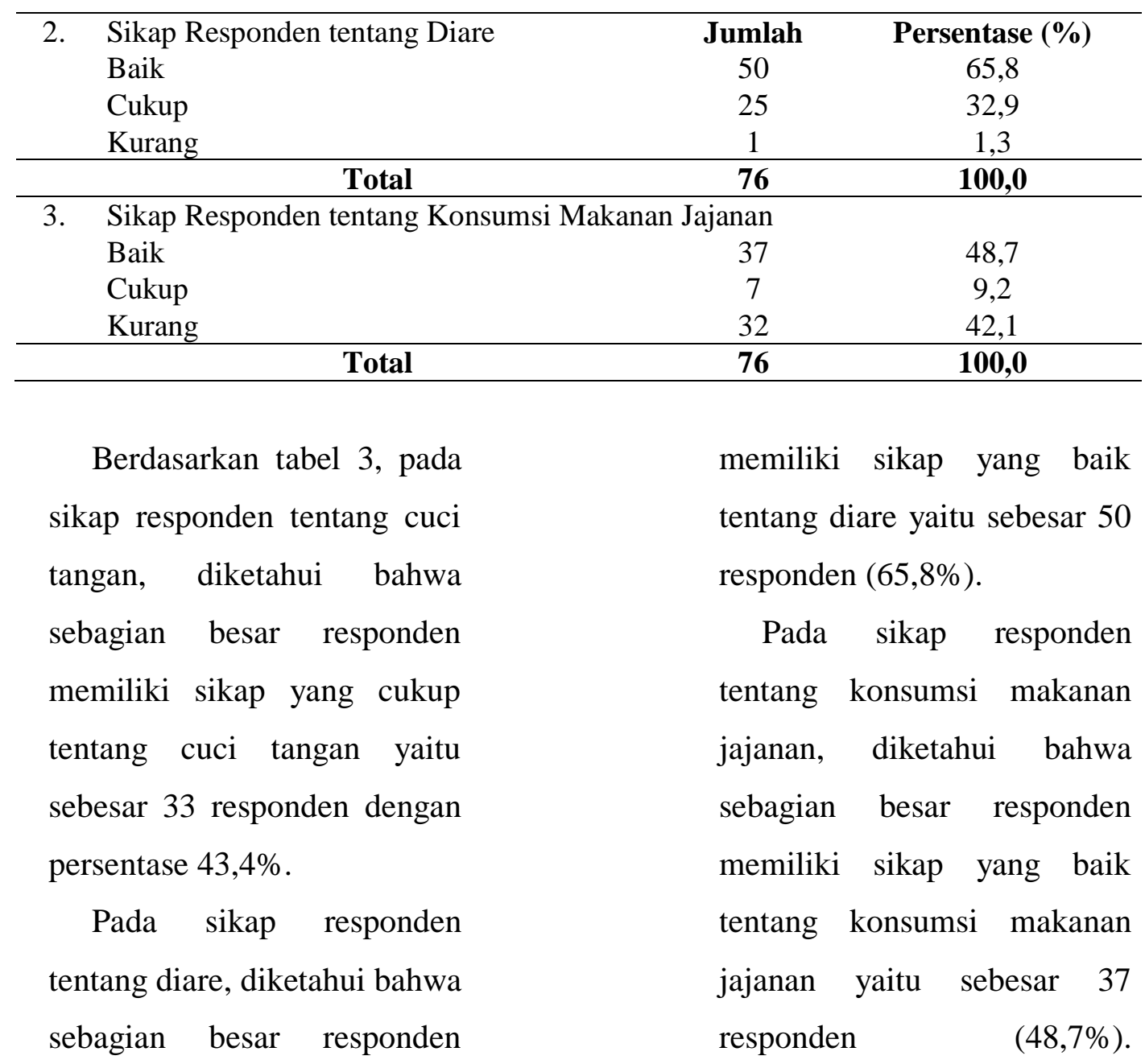

\section{d. Perilaku Responden}

Perilaku responden dapat

dijelaskan dalam tabel berikut:

Tabel 4. Perilaku Responden

\begin{tabular}{|c|c|c|c|}
\hline No. & Pengetahuan Responden & Jumlah & Persentase $(\%)$ \\
\hline \multirow[t]{5}{*}{1.} & Perilaku Responden tentang Cuci Tangan & & \\
\hline & Baik & 44 & 57,9 \\
\hline & Cukup & 16 & 21,1 \\
\hline & Kurang & 16 & 21,1 \\
\hline & Total & 76 & 100,0 \\
\hline \multirow[t]{5}{*}{2.} & Perilaku Responden tentang Konsumsi M & n Jajanan & \\
\hline & Baik & 31 & 40,8 \\
\hline & Cukup & 33 & 43,4 \\
\hline & Kurang & 12 & 15,8 \\
\hline & Total & 76 & 100,0 \\
\hline
\end{tabular}

Berdasarkan tabel 4, sebagian besar responden perilaku responden tentang memiliki perilaku cuci tangan cuci tangan, diketahui bahwa 
yang baik yaitu sebesar 44

responden $(57,9 \%)$.

Pada perilaku responden

tentang konsumsi makanan

jajanan diketahui bahwa

\section{e. Riwayat Kejadian Diare}

Riwayat tentang kejadian diare yang dialami oleh sebagian besar responden

memiliki perilaku konsumsi makanan jajanan yang cukup yaitu sebesar 33 responden $(43,4 \%)$.

responden dapat dijelaskan dalam tabel di bawah ini:

Tabel 5. Riwayat Kejadian Diare

\begin{tabular}{|c|c|c|}
\hline Riwayat Kejadian Diare & Jumlah & $\begin{array}{c}\text { Persentase } \\
(\%)\end{array}$ \\
\hline Pernah & 44 & 57,9 \\
\hline Tidak pernah & 32 & 42,1 \\
\hline Total & 76 & 100,0 \\
\hline
\end{tabular}

Berdasarkan tabel 5 diketahui bahwa sebagian besar responden pernah mengalami kejadian diare yaitu sebesar 44 responden $(57,9 \%)$.

\section{Hasil Analisis Bivariat}

\section{a. Hubungan Pengetahuan}

\section{dengan Kejadian Diare}

1) Hubungan Pengetahuan Cuci

Tangan dengan Kejadian

Diare

Hubungan pengetahuan cuci tangan dengan kejadian

diare dapat dijelaskan dalam tabel berikut ini:

Tabel 6. Hasil Analisis Hubungan Pengetahuan Cuci Tangan dengan Kejadian Diare

\begin{tabular}{lccccccc}
\hline \multirow{2}{*}{$\begin{array}{c}\text { Pengetahuan } \\
\text { Cuci Tangan }\end{array}$} & \multicolumn{4}{c}{ Kejadian Diare } & \multicolumn{2}{c}{ Total } & \multirow{2}{*}{ P value } \\
\cline { 2 - 6 } & \multicolumn{2}{c}{ Tidak Pernah } & \multicolumn{2}{c}{ Pernah } & & \\
\cline { 2 - 6 } & $\mathbf{N}$ & $\mathbf{\%}$ & $\mathbf{N}$ & $\mathbf{\%}$ & $\mathbf{N}$ & $\mathbf{\%}$ & \\
\hline Baik & 39 & 73,6 & 14 & 26,4 & 53 & 100,0 & \\
Cukup & 4 & 30,8 & 9 & 69,2 & 13 & 100,0 & 0,000 \\
Kurang & 1 & 10,0 & 9 & 90,0 & 10 & 100,0 & \\
\hline
\end{tabular}

Berdasarkan tabel 6

diketahui bahwa melalui hasil uji statistik diperoleh nilai $p$ value $=0,000$. Hal ini 
menunjukkan ada atau

variabel pengetahuan cuci

terdapat hubungan antara

tangan dengan kejadian diare.

2) Hubungan Pengetahuan Diare

dengan Kejadian Diare

Hubungan pengetahuan

diare dengan kejadian diare

dapat dijelaskan dalam tabel

berikut ini:

Tabel 7. Hasil Analisis Hubungan Pengetahuan Diare dengan Kejadian Diare

\begin{tabular}{lccccccc}
\hline \multirow{2}{*}{ Pengetahuan Diare } & \multicolumn{4}{c}{ Kejadian Diare } & Total & \multirow{2}{*}{ P value } \\
\cline { 2 - 6 } & $\begin{array}{c}\text { Tidak } \\
\text { Pernah }\end{array}$ & Pernah & & & \\
\cline { 2 - 7 } & $\mathbf{N}$ & $\mathbf{\%}$ & $\mathbf{N}$ & $\mathbf{\%}$ & $\mathbf{N}$ & $\mathbf{\%}$ & \\
\hline Baik & 44 & 91,7 & 4 & 8,3 & 48 & 100,0 & \\
Cukup & 0 & 0,0 & 26 & 100,0 & 26 & 100,0 & 0,000 \\
Kurang & 0 & 0,0 & 2 & 100,0 & 2 & 100,0 & \\
\hline
\end{tabular}

Berdasarkan tabel 7

menunjukkan ada atau

diketahui bahwa melalui hasil

terdapat hubungan antara

uji statistik diperoleh nilai $p$

variabel pengetahuan diare

value $=0,000$. Hal ini

dengan kejadian diare.

3) Hubungan Pengetahuan

Konsumsi Makanan Jajanan

dengan Kejadian Diare

Hubungan pengetahuan

dijelaskan dalam tabel berikut

konsumsi makanan jajanan ini:

dengan kejadian diare dapat

Tabel 8. Hasil Analisis Hubungan Pengetahuan Konsumsi Makanan Jajanan dengan Kejadian Diare

\begin{tabular}{|c|c|c|c|c|c|c|c|}
\hline \multirow{3}{*}{$\begin{array}{c}\text { Pengetahuan } \\
\text { Konsumsi Makanan } \\
\text { Jajanan }\end{array}$} & \multicolumn{4}{|c|}{ Kejadian Diare } & \multirow{2}{*}{\multicolumn{2}{|c|}{ Total }} & \multirow{3}{*}{$P$ value } \\
\hline & \multicolumn{2}{|c|}{$\begin{array}{c}\text { Tidak } \\
\text { Pernah }\end{array}$} & \multicolumn{2}{|c|}{ Pernah } & & & \\
\hline & $\mathbf{N}$ & $\%$ & $\mathbf{N}$ & $\%$ & $\mathbf{N}$ & $\%$ & \\
\hline Baik & 44 & 91,7 & 4 & 8,3 & 48 & 100,0 & \\
\hline Cukup & 0 & 0,0 & 26 & 100,0 & 26 & 100,0 & 0,000 \\
\hline Kurang & 0 & 0,0 & 2 & 100,0 & 2 & 100,0 & \\
\hline
\end{tabular}

Berdasarkan tabel 8

diketahui bahwa melalui hasil

uji statistik diperoleh nilai $p$

value $=0,000$. Hal ini menunjukkan ada atau terdapat hubungan antara 
variabel pengetahuan dengan kejadian diare.

konsumsi makanan jajanan

\section{b. Hubungan Sikap dengan}

\section{Kejadian Diare}

1) Hubungan Sikap Cuci Tangan dengan Kejadian Diare

Hubungan sikap cuci tangan dengan kejadian diare

dapat dijelaskan dalam tabel berikut ini:

Tabel 9. Hasil Analisis Hubungan Sikap Cuci Tangan dengan Kejadian Diare

\begin{tabular}{lccccccc}
\hline \multirow{3}{*}{$\begin{array}{c}\text { Sikap Cuci } \\
\text { Tangan }\end{array}$} & \multicolumn{4}{c}{ Kejadian Diare } & \multicolumn{2}{c}{ Total } & \multirow{2}{*}{ P value } \\
\cline { 2 - 6 } & Pernah & \multicolumn{2}{c}{ Pernah } & & & \\
\cline { 2 - 7 } & N & \% & N & \% & N & \% & \\
\hline Baik & 13 & 92,9 & 1 & 7,1 & 14 & 100,0 & \\
Cukup & 28 & 84,8 & 5 & 15,2 & 33 & 100,0 & 0,000 \\
Kurang & 3 & 10,3 & 26 & 89,7 & 29 & 100,0 & \\
\hline
\end{tabular}

Berdasarkan tabel 9

menunjukkan ada atau

diketahui bahwa melalui hasil

terdapat hubungan antara

uji statistik diperoleh nilai $p$

value $=0,000$. Hal ini variabel sikap cuci tangan dengan kejadian diare.

2) Hubungan Sikap Diare dengan

Kejadian Diare

Hubungan sikap diare dijelaskan dalam tabel berikut dengan kejadian diare dapat ini:

Tabel 10. Hasil Analisis Hubungan Sikap Diare dengan Kejadian Diare

\begin{tabular}{|c|c|c|c|c|c|c|c|}
\hline \multirow{3}{*}{ Sikap Diare } & \multicolumn{4}{|c|}{ Kejadian Diare } & \multirow{2}{*}{\multicolumn{2}{|c|}{ Total }} & \multirow{3}{*}{$P$ value } \\
\hline & \multicolumn{2}{|c|}{$\begin{array}{l}\text { Tidak } \\
\text { Pernah }\end{array}$} & \multicolumn{2}{|c|}{ Pernah } & & & \\
\hline & $\mathbf{N}$ & $\%$ & $\mathbf{N}$ & $\%$ & $\mathbf{N}$ & $\%$ & \\
\hline Baik & 42 & 84,0 & 8 & 16,0 & 50 & 100,0 & \\
\hline Cukup & 2 & 8,0 & 23 & 92,0 & 25 & 100,0 & 0,000 \\
\hline Kurang & 0 & 0,0 & 1 & 100,0 & 1 & 100,0 & \\
\hline
\end{tabular}

Berdasarkan tabel 10

diketahui bahwa melalui hasil uji statistik diperoleh nilai $p$ value $=0,000$. Hal ini menunjukkan ada atau terdapat hubungan antara 
variabel sikap diare dengan

kejadian diare.

3) Hubungan Sikap Konsumsi

Makanan Jajanan dengan

Kejadian Diare

Hubungan sikap konsumsi

dijelaskan dalam tabel berikut

makanan jajanan dengan

ini:

kejadian diare dapat

Tabel 11. Hasil Analisis Hubungan Sikap Konsumsi Makanan Jajanan dengan Kejadian Diare

\begin{tabular}{|c|c|c|c|c|c|c|c|}
\hline \multirow{3}{*}{$\begin{array}{c}\text { Sikap Konsumsi } \\
\text { Makanan Jajanan }\end{array}$} & \multicolumn{4}{|c|}{ Kejadian Diare } & \multirow{2}{*}{\multicolumn{2}{|c|}{ Total }} & \multirow{3}{*}{$P$ value } \\
\hline & \multicolumn{2}{|c|}{$\begin{array}{l}\text { Tidak } \\
\text { Pernah }\end{array}$} & \multicolumn{2}{|c|}{ Pernah } & & & \\
\hline & $\mathbf{N}$ & $\%$ & $\mathbf{N}$ & $\%$ & $\mathbf{N}$ & $\%$ & \\
\hline Baik & 35 & 94,6 & 2 & 5,4 & 37 & 100,0 & \\
\hline Cukup & 5 & 71,4 & 2 & 28,6 & 7 & 100,0 & 0,000 \\
\hline Kurang & 4 & 12,5 & 28 & 87,5 & 32 & 100,0 & \\
\hline
\end{tabular}

Berdasarkan tabel 11 terdapat hubungan antara

diketahui bahwa melalui hasil

variabel sikap konsumsi

uji statistik diperoleh nilai $p$

value $=0,000$. Hal ini makanan jajanan dengan

menunjukkan ada atau

kejadian diare. 


\section{c. Hubungan Perilaku dengan}

\section{Kejadian Diare}

1) Hubungan Perilaku Cuci

Tangan dengan Kejadian

Diare

Hubungan perilaku cuci dapat dijelaskan dalam tabel tangan dengan kejadian diare berikut ini:

Tabel 12. Hasil Analisis Hubungan Perilaku Cuci Tangan dengan Kejadian Diare

\begin{tabular}{lccccccc}
\hline \multirow{2}{*}{$\begin{array}{c}\text { Perilaku Cuci } \\
\text { Tangan }\end{array}$} & \multicolumn{3}{c}{ Kejadian Diare } & \multicolumn{2}{c}{ Total } & \multirow{2}{*}{$\begin{array}{c}\text { Tidak } \\
\text { Pernah }\end{array}$} & \multicolumn{2}{c}{ Pernah } & & & P value \\
\cline { 2 - 7 } & $\mathbf{N}$ & \% & N & \% & N & \% & \\
\hline Baik & 41 & 93,2 & 3 & 6,8 & 44 & 100,0 & \\
Cukup & 3 & 18,8 & 13 & 81,2 & 16 & 100,0 & 0,000 \\
Kurang & 0 & 0,0 & 16 & 100,0 & 16 & 100,0 & \\
\hline
\end{tabular}

Berdasarkan tabel 12

diketahui bahwa melalui hasil

uji statistik diperoleh nilai $p$

value $=0,000$. Hal ini menunjukkan ada atau terdapat hubungan antara variabel perilaku cuci tangan dengan kejadian diare.

2) Hubungan Perilaku Konsumsi

Makanan Jajanan dengan

Kejadian Diare

Hubungan perilaku

konsumsi makanan jajanan

dijelaskan dalam tabel berikut

dengan kejadian diare dapat

Tabel 13. Hasil Analisis Hubungan Perilaku Konsumsi Makanan Jajanan dengan Kejadian Diare

\begin{tabular}{|c|c|c|c|c|c|c|c|}
\hline \multirow{3}{*}{$\begin{array}{c}\text { Konsumsi } \\
\text { Makanan Jajanan }\end{array}$} & \multicolumn{4}{|c|}{ Kejadian Diare } & \multirow{2}{*}{\multicolumn{2}{|c|}{ Total }} & \multirow{3}{*}{ P value } \\
\hline & \multicolumn{2}{|c|}{$\begin{array}{c}\text { Tidak } \\
\text { Pernah }\end{array}$} & \multicolumn{2}{|c|}{ Pernah } & & & \\
\hline & $\mathbf{N}$ & $\%$ & $\mathbf{N}$ & $\%$ & $\mathbf{N}$ & $\%$ & \\
\hline Baik & 30 & 96,8 & 1 & 3,2 & 31 & 100,0 & \\
\hline Cukup & 14 & 42,4 & 19 & 57,6 & 33 & 100,0 & 0,000 \\
\hline Kurang & 0 & 0,0 & 12 & 100,0 & 12 & 100,0 & \\
\hline
\end{tabular}

Berdasarkan tabel 13

diketahui bahwa melalui hasil

uji statistik diperoleh nilai $p$ value $=0,000$. Hal ini menunjukkan ada atau terdapat hubungan antara 
variabel perilaku konsumsi

kejadian

diare.

makanan jajanan dengan

\section{DISKUSI}

\section{Hubungan Pengetahuan Cuci Tangan} dengan Kejadian Diare

Berdasarkan hasil penelitian diketahui bahwa sebagian besar responden memiliki pengetahuan yang baik tentang cuci tangan tidak pernah mengalami diare dalam satu bulan terakhir yaitu sebanyak 39 responden dengan persentase $73,6 \%$. Menurut hasil penelitian yang diperoleh melalui uji statistik chi-square diketahui ada atau terdapat hubungan antara pengetahuan cuci tangan dengan kejadian diare ( $p=$ $0,000)$.

Pengetahuan adalah hasil dari tahu yang dapat terjadi setelah seseorang melakukan penginderaan terhadap suatu objek tertentu. Hasil penelitian ini sejalan

\section{Hubungan Pengetahuan Diare dengan}

\section{Kejadian Diare}

Berdasarkan hasil penelitian diketahui bahwa sebagian besar responden memiliki pengetahuan baik tentang diare tidak pernah mengalami diare dalam satu bulan terakhir yaitu sebanyak 44 responden dengan persentase 91,7\%. Sedangkan, sebagian besar responden yang pernah mengalami diare dalam satu bulan terakhir memiliki

dengan penelitian yang dilakukan oleh Fazlin (2013) yang berjudul "Tingkat Pengetahuan Siswa tentang Teknik Mencuci Tangan yang Benar terhadap Kejadian Diare di SDN 01 Pontianak Utara" yang menjelaskan bahwa terdapat hubungan antara tingkat pengetahuan siswa tentang teknik mencuci tangan yang benar dengan kejadian diare. Semakin kurang tingkat pengetahuan siswa tentang teknik mencuci tangan yang benar maka kejadian diare semakin tinggi dan begitu sebaliknya, semakin baik tingkat pengetahuan siswa tentang teknik mencuci tangan yang benar maka kejadian diare semakin rendah.

pengetahuan yang cukup dan kurang tentang diare. Menurut hasil penelitian yang diperoleh melalui uji statistik chisquare diketahui ada atau terdapat hubungan antara pengetahuan diare dengan kejadian diare $(p=0,000)$.

Hasil penelitian ini didukung dengan penelitian yang dilakukan oleh Suyanto (2008) yang menyatakan bahwa ada 
pengaruh pendidikan kesehatan terhadap tingkat pengetahuan siswa setelah diberikan intervensi berupa pendidikan kesehatan.

\section{Hubungan Pengetahuan Konsumsi}

Makanan Jajanan dengan Kejadian Diare

Berdasarkan hasil penelitian
diketahui bahwa sebagian besar
responden memiliki pengetahuan yang
baik tentang konsumsi makanan jajanan
tidak pernah mengalami diare dalam satu
bulan terakhir yaitu sebanyak 44
responden dengan persentase $91,7 \%$.

Menurut hasil penelitian yang diperoleh melalui uji statistik chi-square diketahui ada atau terdapat hubungan antara pengetahuan konsumsi makanan jajanan dengan kejadian diare $(p=0,000)$.

Berdasarkan hasil penelitian ini, maka dapat diketahui bahwa rendahnya pengetahuan tentang konsumsi makanan jajanan berhubungan dengan angka

\section{Hubungan Sikap Cuci Tangan dengan}

\section{Kejadian Diare}

Berdasarkan hasil penelitian diketahui bahwa sebagian besar responden yang pernah mengalami diare dalam satu bulan terakhir memiliki sikap yang kurang tentang cuci tangan yaitu sebanyak 26 responden dengan persentase $89,7 \%$. Menurut hasil penelitian yang
Oleh karena itu, dapat disimpulkan bahwa pendidikan kesehatan meningkatkan pengetahuan siswa tentang penyakit diare.

kejadian diare yang semakin tinggi, dan begitupun sebaliknya. Penelitian ini didukung oleh Febryanto (2016) yang berjudul "Hubungan antara Pengetahuan dan Sikap dengan Perilaku Konsumsi Jajanan Sehat di MI Sulaimaniyah Mojoanung Jombang” yang menjelaskan ada atau terdapat hubungan pengetahuan dengan perilaku pemilihan konsumsi jajanan sehat yaitu sebanyak $77,8 \%$ siswa memiliki perilaku negatif karena memiliki pengetahuan yang tidak baik. Hal ini menandakan bahwa pengetahuan merupakan faktor yang mendukung dalam pemilihan jajanan sehat.

diperoleh melalui uji statistik chi-square diketahui bahwa ada atau terdapat hubungan antara sikap cuci tangan dengan kejadian diare $(p=0,000)$.

Hasil penelitian ini sejalan dengan penelitian yang dilakukan oleh Tampara, dkk (2017) yang berjudul "Hubungan 
Pengetahuan, Sikap, dan Tindakan Mencuci Tangan dengan Kejadian Diare" yang menjelaskan bahwa terdapat hubungan antara sikap mencuci tangan dengan kejadian diare pada siswa, dimana responden yang memiliki sikap kurang baik sebanyak 37 responden, dan 30 responden diantaranya pernah menderita diare.

\section{Hubungan Sikap Diare dengan}

\section{Kejadian Diare}

Berdasarkan hasil penelitian diketahui bahwa sebagian besar responden memiliki sikap yang baik tentang diare tidak pernah mengalami diare dalam satu bulan terakhir. Menurut hasil penelitian yang diperoleh melalui uji statistik chi-square diketahui bahwa ada atau terdapat hubungan antara sikap tentang diare dengan kejadian diare $(p=$ 0,000). Hal ini menunjukkan bahwa jika individu memiliki sikap yang kurang baik tentang diare maka akan dapat

\section{Hubungan Sikap Konsumsi Makanan}

\section{Jajanan dengan Kejadian Diare}

Sikap merupakan kecenderungan bertindak dari individu, berupa respon terhadap stimulus ataupun objek tertentu. Berdasarkan hasil penelitian diketahui bahwa ada atau terdapat hubungan antara sikap konsumsi makanan jajanan dengan kejadian diare $(p=0,000)$. Dalam hal ini,
Sikap mencuci tangan merupakan salah satu cara untuk mencegah terjadinya diare pada siswa. Salah-satu faktor yang dapat mempengaruhi kurangnya sikap cuci tangan pada siswa adalah ketersediaan sarana cuci tangan yang ada di sekolah, seperti tidak tersedianya sabun dan wastafel di sekolah. (Notoatmodjo, 2007).

meningkatkan kejadian diare, dan begitupun sebaliknya.

Sikap baik atau buruknya individu tentang diare sesuai dengan pengetahuan yang dimiliki individu tersebut. Pengetahuan individu yang baik tentang sesuatu hal akan menghasilkan sikap dan langsung berhubungan dengan perilaku individu tersebut. Sikap yang kurang baik pun juga dapat mempengaruhi perilaku individu.

terdapat $87,5 \%$ pernah mengalami diare karena sikap konsumsi makanan jajanan yang kurang, sebanyak 28,6\% mengalami diare karena sikap konsumsi makanan jajanan yang cukup.

Hasil penelitian ini sesuai penelitian Febryanto (2016), berjudul "Hubungan 
antara Pengetahuan dan Sikap dengan Perilaku Konsumsi Jajanan Sehat di MI Sulaimaniyah Mojoangung Jombang” yang menjelaskan bahwa terdapat hubungan antara sikap responden dengan perilaku pemilihan jajanan sehat.

\section{Hubungan Perilaku Cuci Tangan}

\section{dengan Kejadian Diare}

Berdasarkan hasil uji statistik diketahui ada atau terdapat hubungan antara variabel perilaku cuci tangan dengan variabel kejadian diare $(p=$ 0,000). Dalam hal ini, terdapat 16 responden yang memiliki perilaku cuci tangan kurang, dan seluruhnya mengalami diare dalam satu bulan terakhir. Di sisi lain, sebagian besar responden yang berjumlah 41 responden memiliki perilaku cuci tangan yang baik tidak mengalami diare. Oleh karena itu,

\section{Hubungan Perilaku Konsumsi}

\section{Makanan Jajanan dengan Kejadian}

\section{Diare}

Hasil uji statistik menunjukkan bahwa terdapat hubungan antara variabel perilaku konsumsi makanan jajanan dengan variabel kejadian diare $(p=$ 0,000). Dalam hal ini, terdapat 12 responden yang berperilaku kurang baik dalam mengkonsumsi makanan jajanan, dan seluruhnya pernah mengalami diare.
Membiasakan anak membawa bekal ke sekolah dengan menu makanan yang sehat, sehingga anak tidak jajan di warung atau penjual jajanan saat istirahat, akan membuat anak terbebas dari pemilihan jajanan yang salah (Rosa, 2011).

dapat diketahui bahwa perilaku cuci tangan yang baik kemungkinan terkena diare menjadi kecil, sedangkan perilaku cuci tangan yang kurang baik kemungkinan terkena diare semakin besar.

Hal tersebut sesuai dengan pendapat WHO dalam Rosyidah (2014), mencuci tangan dengan sabun telah terbukti mengurangi kejadian diare kurang lebih $40 \%$.

Menurut Li Patric dan Indscript Creative, (2014), diare dapat dicegah dengan cara jangan jajan sembarangan terlebih lagi yang dijajankan di pinggir jalan secara terbuka, cuci tangan sebelum makan, dan menjaga kebersihan alat makan dan minum. Apabila anak tidak membiasakan diri untuk menjaga kebersihan personalnya melalui cuci 
tangan pakai sabun dengan benar, semua kemungkinan penyebaran kuman bakteri dan virus tersebut dapat mengarahkan anak pada keadaan sakit.

\section{SIMPULAN}

Berdasarkan hasil penelitian pada variabel pengetahuan, diperoleh bahwa ada hubungan antara variabel pengetahuan cuci tangan dengan kejadian diare, ada hubungan antara variabel pengetahuan diare dengan kejadian diare, dan ada hubungan antara variabel pengetahuan konsumsi makanan jajanan dengan kejadian diare.

Pada variabel sikap, diketahui bahwa ada hubungan antara variabel sikap cuci

\section{DAFTAR PUSTAKA}

Departemen Kesehatan RI. 2015. Profil Kesehatan Indonesia 2015. Http://www.Depkes.Go.Id/Resource s/Download/Pusdatin/ProfilKesehatan-Indonesia/ProfilKesehatan-Indonesia-2015.Pdf. Diakses 17 Februari 2018.

Departemen Kesehatan RI. 2017. Data dan Informasi. Http://www. Depkes.Go.Id/Resources/Download/ Pusdatin/Lain-Lain/Data\%20dan\% 20informasi\%20kesehatan\%20profil $\%$ 20kesehatan\%20indonesia\%2020 $16 \% 20-\% 20 \% 20$ smaller\%20size $\%$ 20-\%20web.Pdf. Diakses 15 Februari 2018.

Fazlin, S. 2013. Tingkat Pengetahuan Siswa tentang Teknik Mencuci Tangan yang Benar terhadap Kejadian Diare Di SDN 01 Pontianak Utara. Jurnal Proners Vol. 1, No. 1 (2013).

Febriyanto, M. 2016. Hubungan antara Pengetahuan dan Sikap dengan tangan dengan kejadian diare, ada hubungan antara variabel sikap diare dengan kejadian diare, dan ada hubungan antara variabel sikap konsumsi makanan jajanan dengan kejadian diare.

Pada variabel perilaku, diketahui bahwa ada hubungan antara variabel perilaku cuci tangan dengan kejadian diare dan ada hubungan antara variabel perilaku konsumsi makanan jajanan dengan kejadian diare.

Perilaku Konsumsi Jajanan Sehat di MI Sulaimaniyah Mojoagung Jombang. Skripsi. Program Kesehatan Masyarakat. Surabaya.

Li Patric dan Indscript Creative. 2014. Perisai Segala Penyakit. PT. Elex Media Komputindo. Jakarta.

Notoatmodjo, S. 2007. Promosi Kesehatan dan Ilmu Perilaku. Rineka Cipta. Jakarta.

Rosa, R. 2011. Pengetahuan Gizi dan Keamanan Pangan Jajanan serta Kebiasaan Jajan Siswa Sekolah Dasar di Depok dan Sukabumi. Skripsi. IPB. Bogor.

Rosyidah, A. 2014. Hubungan Perilaku Cuci Tangan terhadap Kejadian Diare pada Siswa di Sekolah Dasar Negeri Ciputat 02. Skripsi. Program Studi Ilmu Keperawatan. Jakarta.

Suyanto. 2008. Pengaruh Pendidikan Kesehatan tentang Diare terhadap Pengetahuan dan Sikap Murid dalam Pencegahan Diare di SD 
Negeri Glinggang 1 Pracimantoro

Kabupaten Wonogiri. Skripsi.

Wonogori.

Tampara J.M, B.H.R. Khairupan, dan

Harvani B. 2017. Hubungan
Pengetahuan, Sikap dan Tindakan

Mencuci Tangan dengan Kejadian

Diare pada Siswa SDN Kabupaten

Kepulauan Sangihe. Ejournalhealth Vol. 6, No. 3 (2017). 